\title{
Monitoring of Global Experience of Consolidated Taxation
}

\author{
Mariya A. Troyanskaya \\ Ph.D. in Economics, Associate Professor, Orenburg State University \\ m_troyanskaya@mail.ru
}

\section{Doi:10.5901/mjss.2016.v7n1p410}

\begin{abstract}
In foreign practice, one of the means of fighting with evasion from taxation of interconnected corporations is special regimes of their taxation. Consolidation supposes unification of several interconnected organizations into one taxpayer - however, it should be noted that consolidation is possible only with several kinds of taxes: corporate profit tax, value added tax, and sometimes excises and other taxes. This regime is aimed at unification of tax administration and change of the order of distribution of tax income from their activities between territorial entities. The purpose of the article is to conduct monitoring of the global practice of taxation of consolidated taxpayers, which is caused by significant drawbacks of Russian regime of consolidated taxation which have already shown themselves during a 3-year practice of its use. Special attention is paid to foreign practice of requirements to participation interest of parent company in the capital of subsidiary company, way of regime selection, possibility of participation for non-resident company, and taxes, for calculation and payment of which unification is allowed. The results of the research allowed developing classification of tax consolidation, within such classification features as subjects of consolidation, legislative consolidation, methods of creation, and taxes which are the object of consolidation. Based on the analysis of historical preconditions for emergence of consolidated groups of taxpayers, three stages of emergence of this institute were determined - period of appearance, fledging period, and period of development. During study of foreign practice of unification of companies into consolidated groups for the purpose of calculation of taxes, similarities and differences of regimes in Russia and foreign countries were revealed.
\end{abstract}

Keywords: consolidation, consolidated payers, consolidated group, consolidated taxation.

\section{Introduction}

Consolidated taxation is taxation of the group of interconnected companies. The group of companies is comprised of several organizations (two or more), one of which manages the activities of the others or controls them, so the group structure has a hierarchical nature. The practice of consolidated taxation appeared at the beginning of XX century. A group of companies united into one subject of taxation for the first time in Austria in 1902 - and then such regime was introduced in the USA, Germany, Denmark, the Netherlands, and other countries. In Russia, consolidation regime was applied since 2012 with the introduction of the federal law No. 321-FZ dated November 16, 2011, which implemented into the Russian law on taxes and charges the provisions on consolidated group of taxpayers (CGP). This regime allows groups of companies to calculate the taxable basis in view of general financial and economic result of activities of all members of the group.

\section{Methodology and Results}

The notion of "consolidated taxpayer" appeared at the beginning of the XX century in Austria. The reason for unification of taxation base of the companies was the state's interest in reduction of negative consequences from activities of particular economic subjects. At that, for a good while, decision on consolidation of tax base was made only on the basis of existing judicial practice, as there was no support from legislation (Bannova, 2012).

Also, one of the first states which implemented specific taxation regime for integrated groups was Germany, where special rules of taxation for the Organschaft group of companies were introduced in 1920 (Bondarenko, Gromov \& Malinina, 2013).

In Spain and the USA, use of this taxation mechanism was obligatory at first, as in these countries the progressive scale of corporate profit tax was used, and legislators were fighting the division of business. Correspondingly, consolidation of positive results of financial and economic activities of all enterprises of the group led to the increase of the sum of total tax liabilities. 
After the World War II, the systems of group taxation were actively implemented in European countries - Great Britain, the Netherlands, France, and other countries.

Beginning from 1990s, the institute of consolidated taxpayers has been actively used in many countries of the world according to the principles which emerged in previous periods. In 2002, the consolidated taxation regime was implemented in Australia and Japan. The main purpose of implementation of this regime in Australia and Japan was to create stimuli for development of integration processes in economics. As a result of 2002, the number of deals for creation of new companies through mergers and acquisitions, as well as through division onto new ones, increased in Japan. According to analysts, this growth was a result of the system of consolidated taxation.

Apart from the above countries, the regime of consolidated taxation is used in Austria, Belgium, Great Britain, Hungary, Greece, Denmark, Lithuania, Luxemburg, Mexico, Norway, Portugal, Republic of Cyprus, USA, Czech Republic, Sweden, and Estonia. In one or another form, consolidated taxation is used in 26 of 34 countries of the Organization for Economic Co-operation and Development (Bannova, 2012).

Having studied the history of existence of consolidated taxation, it is possible to conclude that it has the same long history as corporate profit tax. Development of the institute of consolidated taxation could be divided into three stages:

1) period of emergence (before World War II) - Austria (1902), USA (1917), Germany (1920), Denmark (1936);

2) fledging period (after World War II) - Great Britain (1967), the Netherlands (1969), France (1971), Spain (1980);

3) development of taxation system for groups of companies (since 1990s) - Australia (2002), Japan (2002), Italy (2004), Russia (2012) (Troyanskaya, 2014).

The tax consolidation model has been used in the Russian Federation since 2012. It should be noted that the idea of creation of the consolidated taxation system for Russia is not new: it appeared at the stage of development of the project of the Tax Code of the Russian Federation (initial draft law of the Government of the RF dated February 2, 1996, included Chapter 7 "Consolidated group of taxpayers", consisting of seven articles). The articles contained the definition of the notion "consolidated group of taxpayers" and set the terms of its creation, order of registration, right and liabilities of group and its members, specifics of operations for realization of products (works and services) between members of consolidated group, and terms for changing its structure and liquidation. However, in the process of consideration of the document, it was decided to abandon this chapter due to its weak elaboration and lack of experience of tax bodies for working with large taxpayers. As a result of accumulation of certain experience in administration of the largest taxpayers in Russia, there appeared preconditions for implementation of the institute of consolidation of taxpayers (Ermakova, 2014).

Officially, the notion "consolidated group of taxpayers" was introduced into the Russian law by the Federal law dated June 22, 2007, No. 115-FZ"Concerning financial and industrial groups". According to this law, in cases and order, set by the Russian law on taxes, by agreement on creation of financial and industrial group, members of industrial group, working in the sphere of production of goods and services, could be recognized as consolidated group of taxpayers and can maintain aggregated (consolidated) accounting and balance of financial and industrial group. However, due to absence of corresponding norms in the Tax Code of the RF, this norm was not valid (Tax Code of the Russian Federation, 2015).

It should be noted that formation of the model of consolidated groups of taxpayers used in Russia included the usage of experience of consolidated taxation of Germany and France. These countries are peculiar for unification of financial and economic result for one tax - income tax; at that, unification is voluntary - members act as one taxpayer; only unification of the largest taxpayers is provided (Keen \& Konrad, 2013).

Analysis of the practice of tax consolidation allows distinguishing several types of consolidation of taxpayers:

1) as to subjects:

- $\quad$ unification of legal entities (consolidated taxpayer and consolidated group of taxpayers);

- unification of individuals (family consolidation, joint consolidation, individual and joint consolidation);

2) as to legislative recognition:

- legally recognized consolidation;

- actual consolidation;

3) as to taxes;

- consolidation for income tax;

- consolidation for value added tax;

- consolidation for personal income tax;

- consolidation for property tax;

4) as to methods of emergence; 
- voluntary;

- compulsory.

Unification of legal entities is possible in the form of consolidated taxpayer with independent legal personality and through creation of consolidated group of taxpayers. Consolidation of persons in various countries can be conducted in the form of family consolidation (family is recognized as a unit for the purposes of taxation), joint consolidation (spouses jointly fulfill tax liabilities), and individual and joint consolidation (spouses pay general income tax separately).

As to legal recognition, there is legally recognized consolidation and factual consolidation. Legally recognized, or official, consolidation means implementation of special tax regime together with usual taxation regime. Factual or informal consolidation emerges when there are no official special rules of taxation for consolidated groups of companies, but, due to provisions of specific legal norms, companies that form a group (connected companies) can maintain tax accounting on the way that allows speaking about consolidation for the purposes of taxation (Pappa, Sajedi, \& Vella, 2015).

As to taxes which could be the object of consolidation of taxpayers, it is possible to distinguish consolidation for income tax, value added tax, individual income tax, property tax, etc.

In foreign countries, there are various forms (voluntary or compulsory) for use of special rules of taxation for consolidated groups. It depends on tax policy of the state and is determined on the basis of setting ways of achievement of justness, neutrality, and effectiveness of tax system. Compulsory consolidation that divides all taxpayers into individual and unified allows ordering the taxation system, thus providing the equality of tax burden of certain category of taxpayers (Bondarenko, Gromov \& Malinina, 2013).

As is seen, there are a lot of variants of consolidation of taxpayers in foreign countries; in the Russian practice, due to small experience of use of this aspect, the possibility for creation of such associations is rather limited.

All states, depending on the approach to the notion "consolidated taxpayer", could be divided into three groups:

1. countries with tax codes which do not reflect the interconnection between organizations. That is, all organizations of a group are viewed as independent taxpayers, the results of interrelations of which are presented as relations between independent taxpayers;

2. countries with tax codes which do not have a notion "consolidated taxpayer", but the presence of interconnections is not denied;

3. countries which legally allocate the notions "consolidated taxpayer" or "consolidated group of taxpayers". At that, "consolidated taxpayer" is a single taxpayer. In this treatment, the load of fulfillment of tax liabilities can be put on any member of the group. In the second variant, the main organizations received a possibility to take into account financial result of activities of all members of consolidation during calculation and payment of taxes. In this case, operations of transfer of goods, services, and works between organizations for the purpose of taxation are not viewed.

Based on the analyzed approaches, it is possible to distinguish the main attributes of consolidated taxpayers:

- unification as to interdependence,

- creation for the purpose of minimization of tax liabilities;

- tax liabilities of CGT are determined in view of financial and economic result of activities,

- voluntary unification,

- organization-members are viewed as one taxpayer,

- created for the purpose of calculation of one or several taxes,

- created for certain period of time.

As is seen, the distinguished attributes are general and theoretical, and they are specified by public authorities of the countries that use the regime of tax consolidation.

\section{Discussion}

Monitoring of foreign experience of consolidated taxation shows that each country has its own model of tax consolidation, which differs to a varying degree from models of other countries. Many countries allow groups of companies to calculate tax liabilities as unified, i.e., single, taxpayer, or develop special rules for group members, which, actually, can lead to the same result. Tax regulation can be conducted through transfer prices (Troyanskaya \& Tyurina, 2014). Despite the differences, mechanism of work of consolidated taxation always depends on the status of company in group which is the basis for the method of tax consolidation. The purpose of implementation of tax regimes for connected companies is the same - joint taxation of all members of the group. At the same time, methods used for its achievement and setting of special order of taxation are different.

Let us view peculiarities of tax consolidation of various foreign countries: 
1) Australia. Consolidation of companies for the purposes of taxation is performed at will. There is a special regime of consolidated taxation, at which the whole group of companies is viewed as single taxpayer. In order to create tax group, two companies are enough - one of which will be parent one, and another - subsidiary one. A parent company can be only a legal entity which is a tax resident of Australia. At that, it should pay income tax for main rate. There could be no group created by parent company, the shares of which fully belong to another company that is resident of Australia (1987).

In this country, requirements to participation in capital and residence are rather strict. This, consolidated group can be comprised only of companies with 100\% interest. This requirement is built in view of direct and indirect interest in capital which should in any case be $100 \%$. In tax group, not only parent, but all subsidiary companies, should be tax residents of the country. Despite the fact that, for the purposes of taxation, creation of a group with foreign participation is allowed, foreign subsidiary companies also have to be Australian residents. If this is not so, it is impossible to join tax group (Bannova, 2012).

In view of requirement for full control of one company over another, the rule of single accounting policy for consolidated groups is used in Australia for the tax purposes. Calculation of consolidated tax base is performed on the basis of the following principles:

- firstly, any deals between members of consolidated group are not accounted for the purposes of group taxation;

- secondly, all assets and liabilities are accounted on the level of main organization, as each subsidiary company is viewed as its branch for the purposes of income taxation. This is a peculiar feature of the Australian consolidated taxation. Determination of consolidated tax base does not suppose calculation of financial result of each company separately;

- thirdly, for the purposes of formation of consolidated tax base, it is supposed that assets of subsidiary companies belong to the main company, and tax losses of subsidiary companies also belong to the main company. Therefore, movement of assets inside consolidated group cannot be tracked.

In Australia, tax consolidation supposes preparation and filing a single consolidated tax declaration from the group. This liability is imposed on parent company. At that, tax period is not January 1 - December 31, but July 1 - June 30 of the following year. However, consolidated groups with foreign interest are allowed to use standard tax period (Bondarenko, Gromov \& Malinina, 2013);

2) Austria.Consolidated taxation is used voluntarily. Its use by group of connected companies is possible with financial control of parent company over subsidiary one. Financial control in this country is possible when, from the beginning of financial year, parent company owns more than $50 \%$ of voting shares of subsidiary company.

Tax consolidation means that when certain company in a group suffers losses, they are to be amended by means of profit of other companies. This is done on the basis of admission that, for the purposes of taxation, subsidiary company, despite being independent legal entity according to the Austrian laws, is viewed as a branch of parent company (Picciotto, 1992);

3) Great Britain. Tax consolidation is based on the admission that each company of a group (or consortium) should be imposed with corporate income tax separately. The laws on companies of this country do not include provisions which would allow viewing the connected companies as a single taxpayer. In spite of this, there is a set of provisions which take into account the integrity of economic interests of connected companies (i.e., economic integration) and this suppose the possibility of compensation of losses within the group and transfer of assets between companies of one group without emergence of tax liabilities. In order to acquire a right for this, connected companies should correspond to a list of requirements which are set depending on the type of created group. Investment companies of open type cannot be a part of a group.

There are two main forms of tax consolidation in Great Britain: in the form of group and in the form of consortium. In order for a company to be created for the taxation purposes, it is necessary for parent company's interest - direct or indirect - in subsidiary companies to be more than $50 \%$. If consortium is created, it has to include no more than 20 and no less than 2 companies which are residents of Great Britain and each of which has at least $5 \%$ of other company's capital, together - not less than 75 \% (Bondarenko, Gromov \& Malinina, 2013).

However, consortium can pretend only to transfer of losses between their members. A parent company can be a legal entity, regardless of the fact whether it is a resident of Great Britain.

Based on the rules of consolidated taxation in Great Britain, integrated consolidated tax account is not necessary. At the same time, groups of companies should provide consolidated tax accounts as totality of accounts of parent and subsidiary company;

4) Germany. Tax consolidation of companies is voluntary and means that various economic subjects can be 
viewed as single subjects for the taxation purposes. This requires the connected companies that are united into tax group to be the country's residents.

At that, a parent company can be the one that does not use tax exempts. Relations of control which allow connected companies to consolidate for the purposes of taxation are recognized when parent company possesses directly or indirectly $-50 \%$ of voting shares of subsidiary companies. This share leads to emergence of financial integration of companies. However, compliance with this requirement does not mean that consolidated group of taxpayers will include all subsidiary companies, the shares of which belong to parent company in the volume more than $50 \%$. In other words, if there are, for example, five subsidiary companies, controlled by parent company, only some of them are able to enter the group. It should also be noted that members of the group that is created for the taxation purposes, could be subsidiary companies, controlled by parent company indirectly - under the condition that directly controlled forms (which control the specified subsidiary companies) can be or not be a part of the group (Pickhardt \& Prinz, 2014).

There is no requirement in Germany, according to which parent company of consolidated group of taxpayers cannot be controlled by other company. In other words, the controlled company can create a group for the taxation purposes if it has its own subsidiary company, in which it possesses most part of voting shares. It is possible to create a group with foreign participation in Germany. In order to do this, it is necessary for controlling company to have permanent establishment in Germany.

If a company wants to join a group for the taxation purposes, financial integration, which in Germany means relations of control of one company over another, should exist from the beginning of financial year (1987);

5) Denmark. Regime of consolidated taxation is used in a mandatory manner. The only exception is made for international consolidation which means that tax group includes, apart from Danish companies, also foreign organizations. International consolidation acquires voluntary character of use when tax group includes permanent establishments of Danish companies which are located abroad (including real estate property); these are considered to be foreign subjects. In its turn, of a group contains permanent establishments of foreign companies that perform activities in Denmark, such tax consolidation is also mandatory, as it is not deemed international (in this case, all companies of the group are residents).

Consolidation for the taxation purposes, performed in voluntary manner, supposes that after decision on creation of tax group, all group members should enter it (residents and non-residents).

This means that parent company does not have a right to choose companies that will enter a tax group. Besides, after decision on consolidation for the taxation purposes, group with foreign interest can be dissolved based on the decision of companies not sooner than in 10 years.

If companies-residents are affiliated, the rules of consolidated taxation are applied to them in mandatory manner. Thus, rules of consolidated taxation cover all the groups of companies which perform activities in Denmark. At that, type of company or the sphere of its activities does not play any role. Consolidated taxation relieves each company that is a member of consolidated group from liability for paying income tax. In spite of this, they preserve liability to file tax declaration for this tax every year. For the purpose of performing liability for paying the tax on behalf of the whole group, a so-called "administrative" company is appointed, which is the parent company of the group (Babenko, 2014);

6) Spain.Consolidated tax account is prepared according to companies' decision. The exception is made for banks and their subsidiary companies which have to provide such account in a mandatory manner. A parent company in the group can be stock corporation, limited liability company that is founded on the bases of shares, and permanent establishment of foreign company in Spain. At that, subsidiary companies cannot include the ones that are permanent establishments of companies which are non-residents. Tax group cannot contain companies which are exempted from taxes, joint enterprises, and enterprises that group on the basis of economic interest (for example, unions or professional associations).

In order to create a group for the taxation purposes, a parent company should possess - directly or indirectly through other group members - at least $75 \%$ of subsidiary company's capital. Requirement for minimal interest should be fulfilled during the whole tax year, in which consolidated taxation regime is used, beginning from the first day of this year. All subsidiary companies which correspond to the requirement of minimal interest should be included into the group for the taxation purposes. It is impossible to choose these companies. The parent company cannot belong to another company directly or indirectly by $75 \%$ - otherwise, such company does not have a right to create a taxation group (Nielsen, Raimondos-Møller \& Schjelderup, 2010);

7) Italy. For the purposes of taxation, national and international consolidations are used. National consolidation is possible when controlling and controlled companies want to create a group. A company is consideredto be controlled by another company if the latter regarding the former: 
a) directly or indirectly possesses most of its voting shares;

b) directly or indirectly possesses more than $50 \%$ of it;

c) has a right for more than $50 \%$ of its profit.

At that, companies-residents that are fully or partially exempted from corporate income tax do not have a right to join the group for the taxation purposes. Company that is not a country's resident can also become a controlling (parent) company. However, for this it, firstly, should be a resident of the country with which the taxation agreement is signed, and, secondly, perform its activities through permanent establishment in Italy which should contain in its accounts the participation of foreign company on a group. When the decision in favor of taxation consolidation is made, the group, formed for the taxation purposes, should function as a single taxpayer at least for 3 fiscal years.

Realization of the right for selecting the regime of tax consolidation requires the provision of similarity of fiscal year for all consolidated connected companies, i.e., the fiscal year should be the same on the group. For this purpose, fiscal year of the controlled companies is brought to conformity with the fiscal year of controlling company. Despite the fact that fiscal year has 12 months, its beginning in Italy can be in any month of the year. Besides, tax consolidation is possible with agreement of all consolidated companies.

International consolidation can be initiated by controlling company which is an Italian resident. Unlike national consolidation, international one lasts for 5 years. After that, with repeated selection of the tax consolidation regime, the minimal period for use of this regime constitutes 3 years.

International consolidation means that tax group includes subsidiary companies which are not Italian residents. Company that is not Italian resident is deemed controlled by the Italian company if the latter possesses - directly or indirectly - most of voting shares of the former, or possesses - directly or indirectly - 50\% and more of other shares, rights, etc., participates in profit by more than 50\% (Beuselinck \& Deloof, 2014);

8) Latvia. Companies that belong to one consolidated group are allowed to perform transfer of losses among themselves. The group consists of principal company and all of its subsidiary companies.

Parent or subsidiary company should be presented by a subject that is Latvian resident or resident of the state with which Latvia has an agreement in the issues of taxation, or of another state of the European Economic Area, and, at the same time, is not a resident of the third country according to the agreements on the issues of taxation which does not belong to the European Economic area. Minimal requirement for interest of parent company in subsidiary ones is sent at the level of $90 \%$;

9) Luxemburg. Tax consolidation means that financial result of activities of separate companies of a group is added to taxable income of parent company which concentrates the aggregate taxable income. Its size is consolidated tax basis, of which group income tax is paid.

Creation of the group supposes minimal requirement for parent company's interest in subsidiary companies at the level of 95\%. At that, both direct and indirect interest is taken into account. Companies must have no tax subsidies. The consolidation taxation regime cannot be cancelled during 5 years after connected companies switch to it;

10) Mexico. Connected companies are allowed to create consolidated groups for the taxation purposes. There is a set of requirements to that. Firstly, tax group can be created by company in Mexico. Secondly, there is a necessity for at least one subsidiary company, $50 \%$ or more of voting shares of which belong to parent company. At that, indirect interest (through other companies) is also accounted. Thirdly, no other company can possess more than $50 \%$ of voting shares of other companies (under the condition that companies are deemed residents of the countries which have detailed agreement with Mexico regarding information exchange) (Bondarenko, Gromov \& Malinina, 2013);

11) The Netherlands. Minimal interest of parent company in subsidiary ones is $95 \%$ (both direct and indirect interests are possible). In order to create a group for the taxation purposes, parent and all subsidiary companies should be the country's residents - however, this requirement is not strict, as in some cases the group can be joined by companies which are not residents of the country. Thus, foreign companies with permanent establishment in the Netherlands - under the condition of compliance with certain requirements - can enter a group not only as subsidiary, but also as parent companies (Smirnov, 2010).

Parent company is imposed with liability of preparation of consolidated tax declaration;

12) New Zealand. Groups of connected companies use a special taxation regime, which can be applied at will. For the taxation purposes, companies with $100 \%$ interest are deemed consolidated group. This regime has a variety of advantages. Firstly, transfer of assets within the group between companies does not bear tax consequences. Secondly, expenses for compliance with law are reduced, due to the group's right to file only one declaration instead of several from each company. Still, consolidated taxation in this country has some drawbacks. These include additional responsibility of each company in the group for fulfillment of tax liabilities of the group in case of other companies' lack of assets. Besides, the consolidated taxation regime itself is considered to be complex (Bondarenko, Gromov \& Malinina, 2013); 
13) Russia. Consolidated group is a voluntary association of payers of corporate income tax on the basis of agreement on creation of consolidated group of taxpayers in the order and under the conditions set by the Tax Code of the RF, for the purpose of calculation and payment of the corporate income tax in view of total financial result of economic activities of the above taxpayers. At that, minimal share of direct and/or indirect interest of one organization in registered (reserve) capital of other organizations should constitute not less than $90 \%$. There are the following limitations:

- minimal total sum of VAT, excises, corporate income tax, and MPT, paid by the members of CGT for the previous calendar year without taxes paid for transfer of products through customs of the EurAsEC - RUB 10 billion;

- minimal aggregate volume of revenue and other income received by members of CGT for the previous calendar year - RUB 100 billion;

- minimal aggregate cost of all assets of members as of last day of the year prior to the year of creation of CGT - RUB 300 billion.

The Tax Code of the RF supposes the presence of responsible member in consolidate group which is the group member that, according to the agreement on creation of consolidated group of taxpayers, is imposed with liabilities of calculation and payment of corporate income tax for consolidated group of taxpayers and that performs the same rights and bears the same liabilities in legal relations for calculation and payment of the specified tax, as payers of corporate income tax (Tax Code of the Russian Federation, 2015);

14) USA. Tax legislature of the USA allows consolidated taxation of corporations. Group of consolidated corporations can - on the basis of their interests - choose the variant of consolidated taxation that supposes filing the tax declaration that is common for the whole group. Consolidated taxation is possible under the conditions of principal organization, which is common for all members of associated corporations and which should possess $80 \%$ of shares of each of the corporations of the group. Consolidated taxation of related corporations allows acquiring a range of advantages, including using expenses of one organization for reduction of taxable income of another one, redistribution of income received from certain operations between the group members, and remission of tax on dividends paid within the group. As a rule, foreign company cannot be a member of a group of associated American corporations which have a right for consolidated taxation (Nielsen, Raimondos-Møller \& Schjelderup, 2010).

Despite the fact that tax consolidation is voluntary and is used at companies' will, creation of tax group should suppose the inclusion of all subsidiary companies which conform to the requirement of minimal interest of parent company. As soon as the requirement of minimal interest is fulfilled, the company enters the group. Thus, the quantity of companies which enter tax group can differ from the quantity of connected companies. After unification into tax group, companies have to observe unified tax period. This is due to the fact that tax consolidation in the USA is based on single consolidated tax accounts;

15) Japan. After the tax reform of 2010, the consolidation taxation regime was changed for the purpose of provision of larger correspondence of tax system and order of taxation to economic sense of activities of companies which function on the unified basis through creation of consolidated group.

Consolidated group can be created for the taxation purposes only by the Japanese companies. At that, subsidiary companies should directly or indirectly belong to parent company by $100 \%$. After connected companies have made a choice in favor of filling in the tax declaration on consolidated basis, the group takes in all subsidiary companies, the capital of which fully belongs to principal organization (Bondarenko, Gromov \& Malinina, 2013).

It should be noted that consolidated declaration is filed only for national income tax. As to local taxes, each company should file individual declarations on the basis of own taxable income without losses that could be deducted from it within the group. In order to simplify the order of calculation of taxable income for the purpose of taxation of group and taxation of local taxes, specific elements of taxable income, calculated on the consolidated basis, could be distributed among group members on the simplified basis.

\section{Results}

Thus, having analyzed the peculiarities of consolidated taxation of various countries, it is possible to distinguish their similarities and differences. Let us view the main features of tax consolidation of the above countries in Table 1. 
Table 1 - Main features of consolidated taxation in foreign countries

\begin{tabular}{|c|c|c|c|c|}
\hline State & $\begin{array}{c}\text { Requirement to share participation } \\
\text { of parent company in capital of } \\
\text { subsidiary companies }\end{array}$ & $\begin{array}{c}\text { Method of } \\
\text { regime selection }\end{array}$ & $\begin{array}{c}\text { Possibility for participation of } \\
\text { company which is non-resident }\end{array}$ & $\begin{array}{c}\text { Taxes, for calculation and } \\
\text { payment of which } \\
\text { unification is admitted }\end{array}$ \\
\hline Australia & $100 \%$ & Voluntary & No & Income tax, VAT, etc. \\
\hline Austria & $50 \%$ & Voluntary & No & Income tax, VAT, etc. \\
\hline Great Britain & $50 \%$ & Voluntary & Yes & Income tax \\
\hline Germany & $50 \%$ & Voluntary & Yes & Income tax, VAT, etc. \\
\hline Denmark & $50 \%$ & Compulsory & No & Income tax, VAT, etc. \\
\hline New Zealand & $100 \%$ & Voluntary & No & Income tax, VAT, etc. \\
\hline Spain & $75 \%$ & Voluntary & Yes & Income tax, VAT, etc. \\
\hline Italy & $50 \%$ & Voluntary & No & Income tax, VAT, etc. \\
\hline Latvia & $90 \%$ & Voluntary & No & Income tax, VAT, etc. \\
\hline Luxemburg & $95 \%$ & Voluntary & No & Income tax, VAT, etc. \\
\hline Mexico & $50 \%$ & Voluntary & Yes & Income tax \\
\hline Netherlands & $95 \%$ & Voluntary & No & Income tax, VAT, etc. \\
\hline Russia & $90 \%$ & Voluntary & No & Income tax, VAT, etc. \\
\hline USA & $80 \%$ & & No & \\
\hline Japan & $100 \%$ & & &
\end{tabular}

As is seen, the "softest" conditions for merging into consolidated groups are in Austria, Great Britain, Germany, Denmark, Italy, and Mexico, where the threshold of participation of parent company in capital of subsidiary companies constitutes $50 \%$; the toughest requirements to applicants for participation on groups are set in Australia, New Zealand, and Japan, where the participation interest in subsidiary companies has to constitute $100 \%$.

Also, it is necessary to compare the regimes of tax consolidation of Russia and the viewed foreign countries as to several features (Table 2).

Table 2 - Comparative analysis of CGT regimes in Russia and other countries

\begin{tabular}{|l|c|c|}
\hline Conditions & Russia & Foreign countries \\
\hline Taxpayers unite and act as single taxpayer & Yes & $\begin{array}{c}\text { Australia, Luxemburg, Netherlands, Denmark, Spain } \\
\text { (permit with tax bodies), Germany, Cyprus, Japan }\end{array}$ \\
\hline Unification only for income tax & Yes & Germany \\
\hline Legal independence of taxpayers after unification & Yes & No \\
\hline Every taxpayer files declaration on their own & No & No \\
\hline Filing one declaration for all taxes & $\begin{array}{c}\text { For corporate } \\
\text { income tax only }\end{array}$ & Australia, Luxemburg, Netherlands, Denmark, Spain \\
\hline $\begin{array}{l}\text { Possibility of participation of group of companies } \\
\text { which are non-residents }\end{array}$ & No & Germany, Denmark, Italy, Netherlands \\
\hline Transfer of losses is not allowed & No & No \\
\hline Unification is compulsory & No & Denmark \\
\hline
\end{tabular}

As is seen, the Russian regime of consolidated taxation slightly differs from foreign countries. It should be noted that formation of the Russian model of CGT used the Germany's experience. It is peculiar for unification of financial and economic result for one tax only - income tax; at that, unification is conducted on voluntary basis; members act as a single taxpayer; unification only of the largest taxpayers is possible.

\section{Conclusions}

In all countries of the world, economic subjects constantly cooperate - this is the basis for market economy; very often, these interrelations are used by organizations as a tool for tax evasion. Peculiarities of financial and economic activities of these interconnected structures require development of special rules of their taxation. In most countries of the world, these rules are presented by special tax regime - consolidated taxation. The regime of tax consolidations began to be used in Europe at the beginning of the XX century, and in Russia it was introduced only in 2012.

Analysis of historical preconditions for emergence of consolidated groups of taxpayers allowed distinguishing three stages of emergence of this institute - period of emergence (before World War II), fledgling period (after World War II), 
and development period (beginning from 1990s). The Russian experience of using the regime of tax consolidation is very "young", so it is necessary to use the foreign experience of consolidated taxation which has more than 100-year history.

The research attempted to develop the classification of tax consolidation, within which such classification features, as consolidation subjects, legislative recognition, methods of emergence and taxes, are distinguished, to which consolidation may be applied.

Monitoring of foreign practice of unification of companies into consolidated groups for the purposes of calculation of taxes allowed revealing similarities and differences of regimes in Russia and other countries. Main differences consist in the fact that companies-members abroad are faced with more democratic requirements as compared to the Russian ones; besides, in most developed foreign countries, tax consolidation covers almost all taxes, unlike in Russia, where consolidation, as is known, is possible only for income tax.

Based on the above, it is possible to conclude that most developed countries use in practice consolidated taxation. Implementing the regime of tax consolidation, a range of countries set rather tough requirements to applicants for usage of this subsidy. This is caused by the necessity to prevent misuses from taxpayers by means of one-time use of peculiarities of calculation of tax base within the group. However, recently there is a tendency for expansion of the circle of potential members of consolidated groups of taxpayers by means of reduction of minimal share of parent companies in the capital of subsidiary ones.

\section{References}

Babenko, D.A. (2014). On the development of foreign practice of the concept of consolidated taxation. Transport business in Russia, 1 , 237-237.

Bannova, K.A. (2012). Features of the taxation of the consolidated taxpayers in developed foreign countries. Bulletin of Tomsk State University, 2, 77-80.

Beuselinck, C. \& Deloof, M. (2014). Earnings Management in Business Groups: Tax Incentives or Expropriation Concealment? The International Journal of Accounting, 49, 27-52.

Bondarenko, O.U., V.V. Gromov \& T.A. Malinina, (2013). Foreign experience of the application of special rules for the tax on corporate income for the consolidated group of taxpayers. Moscow: VPO "Russian Academy of National Economy and Public Administration under the President of the Russian Federation".

Ermakova, E.A. (2014). Institute of consolidated taxation: the problem of coordination of interests of taxpayers and the budgetary possibilities. The Economy.Taxes.Right. 3, 93-97.

Keen, M. \& Konrad, K.A. (2013). Chapter 5 - The Theory of International Tax Competition and Coordination. Handbook of Public Economics, 5, 257-328.

Law of the Russian Federation "Tax Code of the Russian Federation" (1998) [Online] Available: http:// www.consultant.ru (July 7, 2015)

Nielsen, S.B., Raimondos-Møller, P. \& Schjelderup, G. (2010). Company taxation and tax spillovers: Separate accounting versus formula apportionment. European Economic Review, 54, 121-132.

Pappa, E., Sajedi, R., \& Vella, E. (2015). Fiscal consolidation with tax evasion and corruption. Journal of International Economics, 96, 56-75.

Picciotto, S. (1992). International taxation and intrafirm pricing in transnational corporate groups. Accounting, Organizations and Society, 17, 759-792.

Pickhardt, M. \& Prinz, A. (2014). Behavioral dynamics of tax evasion - A survey. Journal of Economic Psychology, 40, 1-19.

Smirnov, D.M. (2010). Actual problems of tax consolidated groups abroad and in Russia. International accounting, 5, 33-39.

The derived demand for consolidated financial reporting (1987). Journal of Accounting and Economics, 9, 259-285.

Troyanskaya, M.A. \& Y.G. Tyurina (2014). The Modern Practice of Using the Tax Regulation Instruments. Asian Social Science, 23(10), 184-190.

Troyanskaya, M.A. (2014). A retrospective analysis of the formation and development of the consolidated taxation. Bulletin of the Orenburg State University, 14, 361-365. 